\title{
PENGARUH MEDIA TANAM \\ TERHADAP PERTUMBUHAN DAN HASIL TANAMAN JAMUR TIRAM PUTIH (Pleurotus florida)
}

\author{
Murdaningsih ${ }^{1}$, Modesta Lue ${ }^{2}$ \\ Ningsih_murda@yahoo.co.id \\ Program Studi Agroteknologi, Fakultas Pertanian-Universitas Flores
}

\begin{abstract}
This study aims at revealing the impact of plant media on the growth and yield of white oyster mushroom (Pleurotusflorida) and finding out what plant media that can give the optimal growth and yield.

The design uses in this study was random block design with the treatment of Mbayam (Bayam wood powder), Mmeranti (Meranti wood powder), Mkemiri (Hazelnut wood powder), Mjerami (straw). The observation variables used in this study were the prime emergence of the fruit, the number of fruit clumps, number of fruits per clump, harvesting age, diameter of fruit, the length of fruit stalk, harvesting interval, the weight of the fruit, and REB value.

The result of the study indicated that straw planting media was not be able to grow mushroom and was contaminated. Planting media of bayam wood powder with Meranti wood powder, Bayam wood powder with hazelnut wood powder, and Bayam wood powder with straw makes a difference respectively, as follows: the primary emergence of fruit was 54:58 hst, 54:57 hst, and 54:0 hst, the number of fruit clumps were 18,1\%, $28,8 \%$, and $100 \%$, the number of fruit per clump were $4,0 \%, 13,9 \%$, and $100 \%$, and harvesting age were 4,1:4,9, 4,1:4,1, and 4,1:0. Planting media of Bayam wood powder provided the high average in the primary emergence of fruit of $54 \mathrm{hst}, 118.7$ of fruit clumps, 15.1 of fruit/clump, $6 \mathrm{~cm}$ of fruit diameter, $2.9 \mathrm{~cm}$ length of fruit stalk, 6.6 days of harvesting interval, 68.9 gram of fruit weight and 0.68 of REB value.
\end{abstract}

\section{Keywords: Plant Media, The Growth and Yield, White Oyster Mushroom}

\section{Pendahuluan}

Jamur tiram (Pleurotus florida) merupakan jamur yang banyak digemari oleh masyarakat. Selain kelezatannya, jamur tiram juga sangat bermanfaat bagi kesehatan tubuh. Kandungan gizinya yang tinggi dengan berbagai macam asam amino esensial yang terkandung didalamnya. Jamur tiram juga mengandung senyawa-senyawa lainnya yang penting bagi aspek medis. Pada masyarakat Jepang dan Cina, menu makanan yang terbuat dari jamur sudah menjadi menu turun temurun karena 
Murdaningsih: Pengaruh media tanam terhadap pertumbuhan dan hasil tanaman jamur tiram putih (Pleurotus florida)

mengetahui khasiatnya yang sangat baik bagi tubuh. Indonesi konsumsi jamur tiram dari tahun ke tahun diketahui semakin meningkat seiring dengan kebutuhan masyarakat akan produk pangan yang sehat dan terjangkau.

Di kabupaten Ende ada beberapa petani yang mengusahakan budidaya jamur tiram salah salah satunya adalah wolowona masroom jamur (hasil survei dilapangan). Rata-rata produksi jamur perhari tidak stabil berkisar antara $1 \mathrm{~kg}$ sampai dengan $15 \mathrm{~kg}$ per hari. Salah satu yang menjadi kendala dalam usaha budidaya jamur tiram adalah belum tepatnya komposisi media tempat tumbuh jamur untuk produksi yang tinggi dan bertahan lama.

Media tanam yang digunakan wolowona masroom jamur dalam membudidaya jamur tiram adalah serbuk kayu dengan bahan tambahan tepung jagung, bekatul, kalsit, dan EM4. Serbuk kayu yang digunakan sebagai media tanam merupakan campuran dari beberapa jenis kayu. Menurut pemilik wolowona masroom jamur bahwa penentuan takaran media tanam berdasarkan pengalaman dan tidak ada takaran baku dalam menentukan jumlah media tanam dan bahan campuran lainnya.
Menurut Djarijah dan Djarijah (2001), jamur tiram tumbuh pada tempat-tempat yang mengandung nutrisi berupa senyawa karbon, nitrogen, vitamin dan mineral. Karbon digunakan sebagai sumber energi sekaligus unsur pertumbuhan. Nitrogen diperlukan dalam sintesis protein, purin, dan pirimidin.Vitamin seperti B1, B2, B5 dan B7 diperlukan sebagai katalisator sekaligus sebagai koenzim. Unsur mineral untuk pertumbuhan jamur meliputi unsure makro (K, $\mathrm{P}, \mathrm{Ca}, \mathrm{Mg}$ dan lain-lain) dan unsur mikro $(\mathrm{Cu}, \mathrm{Zn}$, dll).

Sutarman (2012), Kombinasi perlakuan media ampas tebu dan dedak memberikan respons terbaik jamur tiram putih dalam hal kecepatan tumbuh miselium, waktu pertumbuhan relatif bakal buah, diameter maksimum tudung buah, dan bobot panen per baglog, Kombinasi perlakuann ampas tebu dan tepung jagung memberikan respons terbaik dalam kualitas tubuh buah yang didukung oleh jumlah tubuh buah dan bobot tubuh buah terbaik, serta diameter tudung buah dan indeks rasio bobot terhadap diameter tudung buah yang tinggi.

Agus Mulyadi, dkk (2012) Pemberian 22,5 kg bekatul/100 kg 
Murdaningsih: Pengaruh media tanam terhadap pertumbuhan dan hasil tanaman jamur tiram putih (Pleurotus florida)

serbuk gergaji dapat mempercepat dan memperbanyak periode panen, meningkatkan jumlah tubuh buah, diameter tudung jamur dan total bobot segar jamur. Sedangkan pemberian SP36 dan interaksi antara pemberian bekatul dan SP36 secara garis besar tidak berpengaruh nyata terhadap semua variabel (pemunculan tubuh buah pertama, jumlah rumpun tubuh buah, jumlah tubuh buah/rumpun, umur panen, diameter tudung buah, panjang tangkai tubuh buah, interval panen, bobot tubuh buah dan nilai REB).

Noer Arief Kurniawan (2012), terdapat pengaruh interaksi yang nyata antara perlakuan jenis serbuk kayu gergaji dan jenis jamur tiram terhadap berat segar total jamur, berat kering jamur tiram dan efisiensi biologis. Kombinasi kayu sengon dan jamur tiram putih merupakan kombinasi yang paling baik dibanding kombinasi perlakuan lainnya. Perlakuan faktor tunggal jenis serbuk kayu berpengaruh nyata terhadap saat munculnya miselium, saat munculnya badan buah dan diameter badan buah. Jenis serbuk kayu yang baik adalah jenis kayu sengon. Perlakuan faktor tunggal jenis jamur tiram berpengaruh nyata pertumbuhan saat munculnya miselium, saat munculnya badan buah dan diameter badan buah. Jenis jamur tiram putih lebih baik dibandingkan dengan jamur tiram merah dan abu-abu.

Pada dataran rendah modifikasi bahan media serta takarannya dapat mengoptimalkan hasil dalam usaha budidaya jamur tiram, caranya dengan mengurangi dan menambah takaran tiap-tiap dari bahan standar umumnya. Pada usaha budidaya jamur tiram skala kecil, perlu juga dilakukan eksperimen atau percobaan dalam menentukan takaran media agar takarannya tepat. Hal ini diperlukan dilakukan mengingat jamur yang dibudidayakan di lingkungan tumbuh yang berbeda tentu membutuhkan nutrisi dan media yang berbeda pula tergantung pada kondisi lingkungan setempat. Hingga saat ini belum ada standar komposisi media untuk budidaya jamur tiram di dataran rendah, sehingga petani memodifikasi media dan lingkungan berdasarkan pengalaman dan kondisi masingmasing. Karena itu penelitian dengan judul “ Pengaruh Media Tanam Terhadap Pertumbuhan dan Hasil Tanaman Jamur Tiram Putih (Pleurotus florida)" dianggap penting untuk dilakukan sebagai acuan dalam 
Murdaningsih: Pengaruh media tanam terhadap pertumbuhan dan hasil tanaman jamur tiram putih (Pleurotus florida)

pengembangan budidaya jamur di kota Ende.

\section{Metodologi Penelitian}

\section{Tempat dan Waktu Penelitian}

Penelitian dilakukan di Wolowona Masroom Jamur Kelurahan Rewarangga Selatan Kecamatan Ende Timur. Kegiatan ini dilaksanakan selama 3 bulan dari bulan April sampai dengan Juli 2014. Dengan ketinggian tempat $35 \mathrm{~m}$ dpl, suhu rata-rata $28^{\circ} \mathrm{C}$ dan kelembaban udara rata-rata $80,90 \%$ (BPS Ende, 2014).

\section{Bahan dan Alat Penelitian}

Bahan-bahan yang digunakan dalam penelitian ini adalah bibit jamur tiram putih (Pleurotus florida), serbuk kayu bayam, serbuk kayu meranti, serbuk kayu kemiri, jerami, dedak/bekatul, tepung jagung, kalsit (CaCO3), TSP, air, plastik PP (polypropilen) dengan ukuran 18x30 $\mathrm{cm}$, karet gelang, penutup plastik, kapas dan lembaran kertas ukuran 10x10 cm, alkohol $96 \%$ dan $70 \%$.

Alat-alat yang digunakan dalam penelitian ini adalah sekop, ayakan, ruang sterilisasi, alat untuk memadatkan media, pipa paralon, spatula, cutter, lembar plastik lebar, knapsack sprayer, handsprayer, meteran, timbangan, penggaris dan alat tulis.

\section{Rancangan Penelitian}

Penelitian ini menggunakan Rancangan Acak Kelompok (RAK) yaitu dengan 4 perlakuan masingmasing 20 baglog, dimana setiap perlakuan diulang sebanyak 5 kali sehingga terdapat 80 baglog.

Jenis media tanam yaitu :

M1 : Serbuk kayu Bayam

M2 : Serbuk kayu Meranti

M3 : Serbuk kayu Kemiri

M4 : Jerami

\section{Pelaksanaan Penelitian}

Pelaksanaan penelitian meliputi: Sanitasi Ruang Inkubasi, Persiapan Media Tanam, Perlakuan Media Tanam, Pengomposan, Pengisian Media, Sterillisasi, Pendinginan, Inokulasi, Inkubasi (Spawing), Penumbuhan (Growing), Pemeliharaan, Penyiraman, Pemisahan, Pengendalian Hama dan Penyakit dan Pemanenan.

\section{Variabel Pengamatan}

Variabel pengamatan dalam penelitian ini meliputi Variabel Pertumbuhan (Pemunculan Tubuh Buah Pertama, Jumlah Rumpun Tubuh Buah, Jumlah Tubuh Buah/Rumpun, dan Umur Panen) serta Variabel Hasil (Diameter Tudung Tubuh Buah, Panjang Tangkai Tudung tubuh buah, 
Murdaningsih: Pengaruh media tanam terhadap pertumbuhan dan hasil tanaman jamur tiram putih (Pleurotus florida)

Interval Panen, Bobot Tubuh Buah dan

Nilai Rasio Efisiensi Biologis.

\section{Analisis Data}

Data yang diperoleh ditransformasikan dengan menggunakan Log+10 karena dalam hasil penelitian ini media tanam jerami (M4) jamur tidak dapat tumbuh. Data hasil transformasi tersebut di analinisis dengan menggunakan analisis sidik ragam sesuai dengan rancangan yang digunakan. Apabila perlakuan menunjukkan pengaruh yang nyata atau sangat nyata terhadap variabel yang diamati, maka pengujian dilanjutkan dengan uji nilai beda rata-rata menggunakan uji BNT 5\% (Gomez dan Gomez, 2007).

\section{Hasil Dan Pembahasan}

Hasil analisis statistika menunjukan bahwa perlakuan media tanam (serbuk kayu bayam, serbuk kayu meranti serbuk kayu kemiri dan jerami) berpengaruh sangat nyata terhadap semua variabel pertumbuhan (pemunculan tubuh buah pertama, jumlah rumpun tubuh buah, jumlah tubuh buah/rumpun, dan umur panen), dan juga pada semua variabel hasil (diameter tudung tubuh buah, panjang tangkai tudung tubuh buah, interval panen, bobot tubuh buah dan nilai rasio efesiensi biologis/REB). Hal ini dipengaruhi oleh kandungan bahan organik masing-masing media tanam berbeda, dimana serbuk kayu bayam, meranti dan kemiri mengandung selulosa dan lignin yang berguna bagi pertumbuhan dan hasil jamur tiram.

Tabel 4.1 Signifikan Pengaruh Media Tanam Terhadap Pertumbuhan dan Hasil Jamur Tiram Putih (Pleurotus florida)

\begin{tabular}{clc}
\hline No & \multicolumn{1}{c}{ Variabel } & Signifikan \\
\hline 1 & Pemunculan Tubuh Buah Pertama (hari) & $* *$ \\
2 & Jumlah Rumpun Tubuh Buah (buah) & $* *$ \\
3 & Jumlah Tubuh Buah/rumpun (buah) & $* *$ \\
4 & Umur Panen (hari) & $* *$ \\
5 & Diameter Tudung Tubuh Buah $(\mathrm{cm})$ & $* *$ \\
6 & Panjang Tangkai Tubuh Buah $(\mathrm{cm})$ & $* *$ \\
7 & Interval Panen (hari) & $* *$ \\
8 & Bobot Tubuh Buah $(\mathrm{g})$ & $* *$ \\
9 & Nilai REB & \\
\hline
\end{tabular}

Keterangan :

** : Sangat nyata

\section{Variabel pertumbuhan}


Murdaningsih: Pengaruh media tanam terhadap pertumbuhan dan hasil tanaman jamur tiram putih (Pleurotus florida)

Hasil analisis sidik ragam pemunculan tubuh buah pertama, menunjukan bahwa perlakuan media jumlah rumpun tubuh buah, jumlah tanam serbuk bayam, serbuk meranti, tubuh buah/rumpun dan umur panen serbuk kemiri dan jerami memberikan (Tabel 4.2).

pengaruh yang sangat nyata terhadap

Tabel 4.2 Pengaruh Media Tanam terhadap pemunculan tubuh buah pertama, jumlah rumpun tubuh buah, jumlah tubuh buah/rumpun dan umur panen.

\begin{tabular}{ccccc}
\hline Perlakuan & $\begin{array}{c}\text { Pemunculan } \\
\text { Tubuh buah } \\
\text { (hari) }\end{array}$ & $\begin{array}{c}\text { Jumlah rumpun } \\
\text { tubuh buah } \\
\text { (buah) }\end{array}$ & $\begin{array}{c}\text { Jumlah tubuh } \\
\text { buah/rumpun } \\
\text { (buah) }\end{array}$ & $\begin{array}{c}\text { Umur panen } \\
\text { (hari) }\end{array}$ \\
\hline M1 & $53,8000 \mathrm{c}$ & $118,7400 \mathrm{a}$ & $15,1000 \mathrm{a}$ & $4,1000 \mathrm{~b}$ \\
M2 & $58,0000 \mathrm{a}$ & $97,3000 \mathrm{~b}$ & $14,5000 \mathrm{~b}$ & $4,9000 \mathrm{a}$ \\
M3 & $57,4000 \mathrm{~b}$ & $84,5000 \mathrm{c}$ & $13,0000 \mathrm{c}$ & $4,1000 \mathrm{~b}$ \\
M4 & $0,0000 \mathrm{~d}$ & $0,0000 \mathrm{~d}$ & $0,0000 \mathrm{~d}$ & $0,0000 \mathrm{c}$ \\
\hline BNT & 0,0004 & 0,0023 & 0,0034 & 0,0023 \\
\hline
\end{tabular}

Keterangan:

- Angka-angka yang diikuti oleh huruf yang sama pada kolom yang sama menunjukan pengaruh yang tidak berbeda nyata pada taraf uji BNT 5\%.

- Data di transformasikan menggunakan $\log +10$

Hasil analisis sidik ragam digunakan media tanam jerami yang menunjukan bahwa media tanam dari serbuk kayu bayam, meranti, kemiri dan jerami memberikan pengaruh yang sangat nyata terhadap pertumbuhan jamur tiram pada seluruh variabel pertumbuhan. Hal ini menunjukan bahwa hipotesis pertama diterima, dimana media tanam dari serbuk kayu bayam, serbuk kayu meranti, serbuk kayu kemiri memberikan pengaruh yang berbeda terhadap pertumbuhan jamur tiram.

Pada penelitian ini media tanam dari jerami tidak dapat tubuh dan terkontaminasi karena pada media jerami hanya dapat tumbuh jamur merang. Pada budidaya jamur merang telah dicelupkan dengan air sampai air meresap secara merata pada jerami dan ditaburi dengan dedak. Kemudian dilakukan pengomposan dengan menutup media jerami dengan plastik kurang lebih satu minggu dan pada hari ke empat dilakukan pembalikan dan ditaburi kembali dengan dedak dan kapur, kemudian diletakan pada rak dan ditaburi dengan bibit jamur ditutup kembali dan tunggu selama 12 hari untuk memanen jamur-jamurnya.

Perbandingan hasil rata-rata antara media serbuk kayu bayam dengan serbuk kayu meranti, antara media serbuk kayu bayam dan serbuk kayu kemiri dan antara media serbuk 
Murdaningsih: Pengaruh media tanam terhadap pertumbuhan dan hasil tanaman jamur tiram putih (Pleurotus florida)

kayu bayam dan jerami pada semua variabel pertumbuhan secara berurutan sebagai berikut : pemunculan tubuh buah pertama adalah 54:58 hst , 54:57 hst dan 54:0. Dari tabel 4.2 diketahui bahwa nilai rata-rata pemunculan tubuh buah tertinggi secara berurutan yaitu pada media M2, M3,M1 dan M4. Tingginya rata-rata hari pemunculan tubuh buah menunujukan bahwa hari pemunculan tubuh buah pada media M2 lebih lambat dibanding M3 dan M1. Berdasarkan pengamatan dilapangan pemunculan tubuh buah pertama pada media serbuk kayu meranti adalah 56 hst, pada media serbuk kayu kemiri adalah 55 hst, pada media serbuk kayu bayam adalah 50 hst. Nilai 0 pada ratarata pemunculan tubuh buah pertama di media jerami disebabkan karenan pada media tersebut jamur tidak dapat tumbuh dan terkontaminasi.

Hal ini menunjukan bahwa hipotesis kedua terbukti dimana media tanam dengan menggunakan serbuk kayu bayam memberikan hasil yang tinggi terhadap pertumbuhan tanaman jamur tiram. Hal ini sejalan dengan pendapat Menanda, (2013), bahwa bahan serbuk gergaji yang baik dapat diperoleh dari bahan kayu keras karena serbuk gergaji kayu jenis tersebut sangat berpotensi dalam meningkatkan hasil panen jamur tiram. Selanjutnya dikatakan dalam kayu keras karena mengandung selulose lebih banyak ( > $30 \%$ ) dimana solulose ini sangat dibutuhkan oleh jamur. Media tanam yang baik mampu mendukung pertumbuhan dan perkembangan miselium dan mampu menghasilkan jamur yang baik dan masa panen yang lebih lama.

\section{Variabel Hasil}

Hasil analisis sidik ragam pada variabel hasil dapat dilihat pada tabel dibawah ini. Dari hasil analisis sidik ragam menunjukan bahwa masingmasing perlakuan media tanam memberikan hasil yang sangat nyata terhadap semua variabel hasil. Perbedaan rata-rata dari setiap perlakuan menunjukan bahwa hipotesis pertama diterima, dimana media tanam dari serbuk kayu bayam, serbuk kayu meranti, serbuk kayu kemiri dan jerami memberikan pengaruh yang berbeda terhadap hasil jamur tiram.

Tabel 4.3 Pengaruh Media Tanam terhadap diameter tudung tubuh buah, panjang tangkai tubuh buah, interval panen, bobot tubuh buah dan nilai REB. 
Murdaningsih: Pengaruh media tanam terhadap pertumbuhan dan hasil tanaman jamur tiram putih (Pleurotus florida)

\begin{tabular}{cccccc}
\hline Perlakuan & $\begin{array}{c}\text { Diameter } \\
\text { tudung tubuh } \\
\text { buah } \\
(\mathrm{cm})\end{array}$ & $\begin{array}{c}\text { Panjang } \\
\text { Tangkai } \\
\text { Tubuh } \\
\text { buah }(\mathrm{cm})\end{array}$ & $\begin{array}{c}\text { Interval } \\
\text { panen } \\
\text { (hari) }\end{array}$ & $\begin{array}{c}\text { Bobot tubuh } \\
\text { buah } \\
(\mathrm{gr})\end{array}$ & Nilai REB \\
\hline M1 & $6,0000 \mathrm{a}$ & $2,9000 \mathrm{a}$ & $6,6000 \mathrm{~b}$ & $68,9000 \mathrm{a}$ & $0,6780 \mathrm{a}$ \\
M2 & $5,6000 \mathrm{~b}$ & $2,8000 \mathrm{~b}$ & $7,0000 \mathrm{a}$ & $60,8000 \mathrm{~b}$ & $0,5840 \mathrm{~b}$ \\
M3 & $5,3000 \mathrm{c}$ & $2,7000 \mathrm{c}$ & $7,0000 \mathrm{a}$ & $43,2000 \mathrm{c}$ & $0,4340 \mathrm{c}$ \\
M4 & $0,0000 \mathrm{~d}$ & $0,0000 \mathrm{~d}$ & $0,0000 \mathrm{c}$ & $0,0000 \mathrm{~d}$ & $0,0000 \mathrm{~d}$ \\
\hline BNT & 0,0001 & 0,0001 & 0,0019 & 0,0032 & 0,0001
\end{tabular}

\section{Keterangan:}

- Angka-angka yang diikuti oleh huruf yang sama pada kolom yang sama menunjukan pengaruh yang tidak berbeda nyata pada taraf uji BNT 5\%.

- Data di transformasikan menggunakan log+10

Hasil analisis statistik dikatakan dalam kayu keras menunjukan bahwa media serbuk kayu mengandung selulose dalam jumlah bayam memberikan hasil yang tertinggi yang banyak dimana solulose ini sangat pada semua variabel hasil (diameter tudung tubuh buah, panjang tangkai tudung tubuh buah, interval panen, bobot tubuh buah dan nilai REB).

Hasil ini menunjukan bahwa hipotesis kedua terbukti dimana media tanam dengan menggunakan serbuk kayu bayam memberikaan hasil yang optimal karena perbedaan pada ratarata variabel hasil pada masing-masing media tanam dipengaruhi oleh kandungan zat kimia dalam masingmasing media. Hal ini sejalan dengan pendapat Meinanda (2013), bahwa bahan serbuk gergaji yang baik dapat diperoleh dari bahan kayu keras karena serbuk gergaji kayu jenis tersebut sangat berpotensi dalam meningkatkan hasil panen jamur tiram. Selanjutnya dibutuhkan oleh jamur.

Hal ini sesuai dengan pernyataan Chang (1978) dalam Stevani Susi (2011) bahwa jamur akan hidup subur pada bahan-bahan yang melapuk atau terdekomposisi. Bahan organik mengandung yang selulosa dan lignin dalam jumlah yang besar akan mendukung pertumbuhan dan perkembangan tubuh jamur. Selain itu jamur yang ditanam pada substrat yang telah di komposkan akan mempermudah jamur untuk merombak langsung bahanbahan yang mengandung selulosa dan lignin (Zadrazil, 1978, dalam Stevani Susi, 2011).

\section{Kesimpulan}

1. Media tanam jerami tidak dapat ditumbuhi jamur dan 
Murdaningsih: Pengaruh media tanam terhadap pertumbuhan dan hasil tanaman jamur tiram putih (Pleurotus florida)

terkontaminasi. Media tanam serbuk kayu bayam dengan serbuk kayu meranti, antara serbuk kayu bayam dengan serbuk kayu kemiri dan antara serbuk kayu bayam dan jerami memberikan perbedaan secara berurutan sebagai berikut: pemunculan tubuh buah pertama adalah 54:58 hst, 54:57 hst dan 54:0, pada jumlah rumpun tubuh buah adalah jumlah rumpun tubuh buah adalah $18,1 \%, \quad 28,8 \%$ dan $100 \%$, jumlah tubuh buah/rumpun $4,0 \%, 13,9 \%$ dan $100 \%$, dan umur panen 4,1:4,9, 4,1:4,1 dan 4,1:0.

2. Media tanam serbuk kayu bayam memberikan rata-rata hasil yang tinggi pada pemunculan tubuh buah pertama yaitu 54 hst, jumlah rumpun tubuh buah sebanyak 118,7, jumlah tubuh buah/rumpun sebanyak 15,1, diameter tudung tubuh buah $6 \mathrm{~cm}$, panjang tangkai tubuh buah $2,9 \mathrm{~cm}$, interval panen 6,6 hari, bobot tubuh buah/rumpun 68,9 gram dan nilai REB 0,68.

\section{Ucapan Terima Kasih}

Pada kesempatan ini penulis ingin mengucapkan terima kasih kepada semua pihak yang telah membantu dengan caranya masing-masing dalam melengkapi tulisan ini.

\section{Daftar Pustaka}

BPS Ende. 2014. Ende Dalam Angka 2013. BPS. Ende

Cahyana, Y A, Muchroji, M. Bakrun. 2001. Budidaya dan Analisis Jamur Tiram. Penebar Swadaya. Jakarta

Cahyo, N. 2013. Budidaya Jamur dengan Media yang Mampu Bertahan selama 5 Bulan. Magisterpengelana.blogspot.com/2 012/01/.html. 11 Maret 2014

Dinas Pertanian, 2006. Budidaya Jamur Tiram. http://www.diperta jatim go.id/index.php. 10 Maret 2014

Direktorat Jenderal Holtikultura Departemen Pertanian. 2010. Petunjuk Teknis Budidaya Jamur Tiram (Pleurotus ostreotus var florida) yang ramah lingkungan. Forclime.org/merang/50-stelfinal.pdf. 12 Maret 2014 Djarjiah, M N.,Djarijah S A. 2001. Budidaya Jamur Tiram. Kanisius. Yogyakarta.

Dwidjoseputro, D., 1994. Pengantar Fisiologi Tumbuhan. Gramedia Pustaka Utama. Jakarta Meidananda, Ica. 2013. Panen Cepat Budidaya Jamur. Padi. Jakarta 
Murdaningsih: Pengaruh media tanam terhadap pertumbuhan dan hasil tanaman jamur tiram putih (Pleurotus florida)

Moore dan Landecker., 1982. Solo : Universitas Sebelas Maret Fundamental of The Fungi Prentice Surakarta.

Hall, Inc.Englewoo Cliff, new jersey.p 275, 337

Mulyadi, Agus dkk. 2012. Pengaruh takaran bekatul dan pupuk Anorganik terhadap hasil jamur tiram. Jurnal Agroteknologi Fakultas Pertanian Universitas Muhamadiyah Purwekerto.

Noer Arief Kurniawan, 2012. Uji potensi produksi jenis jamur tiram pada berbagai media serbuk kayu. (skripsi). Malang: universitas Muhamadiyah Malang.

Natur Indonesia. 2013. Jamur Pangan. http://naturindonesia.com/jamurpangan.htm. 12 september 2014

Padmiarso, M. Wijoyo. 2011. Cara bertanam Jamur Tiram yang Menguntungkan. Penebar Swadaya. Jakarta.

Rosmarkam, A dan N.W Yuwono., 2002. Ilmu Kesuburan Tanah. Kanisius. Yogyakarta

Sitompul, S.M dan B Guritmo, 1995. Analisis Pertumbuhan Tanaman. UGM Press. Yogyakarta

Steviani, Susi. 2011. Pengaruh Penambahan Molase dalam berbagai Media pada Jamur Tiram (Pleurotus ostreatus). (Skripsi). 